\title{
Cross Talk among TGF- $\beta$ Signaling Pathways, Integrins, and the Extracellular Matrix
}

\author{
John S. Munger ${ }^{1}$ and Dean Sheppard ${ }^{2}$ \\ ${ }^{1}$ Departments of Medicine and Cell Biology, New York University, New York, New York 10016 \\ ${ }^{2}$ Department of Medicine, University of California, San Francisco, San Francisco, California 94143-2922 \\ Correspondence: john.munger@nyumc.org
}

The growth factor TGF- $\beta$ is secreted in a latent complex consisting of three proteins: TGF- $\beta$, an inhibitor (latency-associated protein, LAP, which is derived from the TGF- $\beta$ propeptide) and an ECM-binding protein (one of the latent TGF- $\beta$ binding proteins, or LTBPs). LTBPs interact with fibrillins and other ECM components and thus function to localize latent TGF- $\beta$ in the ECM. LAP contains an integrin-binding site (RGD), and several RGD-binding integrins are able to activate latent TGF- $\beta$ through binding this site. Mutant mice defective in integrin-mediated activators, and humans and mice with fibrillin gene mutations, show the critical role of ECM and integrins in regulating TGF- $\beta$ signaling.

In addition to providing physical support for cells and tissues, the ECM serves as an information-rich structure interpreted by cells through multiple lines of interacting sensory inputs, prominent among which are the integrins (the major receptors used by cells to adhere to ECM components) and growth factor (GF) signaling (Hynes 2009). These three systems (integrins, ECM, and GFs) interact: for example, many GFs are stored within and can be released from ECM-binding sites. Integrins transmit information about the ECM's mixture of components and mechanical properties, and also assemble and rearrange ECM components. Within the cell, integrin and GF signaling pathways extensively cross talk with each other (Streuli and Akhtar 2009; Ivaska and Heino 2010).

Transforming Growth Factor (TGF)- $\beta$ signaling serves as a paradigm of how integrin,
ECM, and GF function are linked. TGF- $\beta$ was isolated as a tumor-secreted factor (de Larco and Todaro 1978; Roberts et al. 1982), and was later shown to exist as three biologically similar isoforms encoded by separate genes. TGF- $\beta$ is synthesized by, and can signal to, essentially all cells, and its actions are wideranging. It inhibits proliferation of many cell types, broadly regulates the immune system (Li et al. 2006), and orchestrates ECM production and proteolytic turnover; for example, TGF- $\beta$ overexpression causes fibrosis (Roberts et al. 1986; Sime et al. 1997). TGF- $\beta$ is released from cells in a latent complex formed by three proteins: TGF- $\beta$, the processed TGF- $\beta$ propeptide, and a member of the latent TGF- $\beta$ binding protein (LTBP) family. LTBPs are microfibrilassociated proteins that tether latent TGF- $\beta$ to the ECM.

Editors: Richard O. Hynes and Kenneth M. Yamada

Additional Perspectives on Extracellular Matrix Biology available at www.cshperspectives.org

Copyright (C) 2011 Cold Spring Harbor Laboratory Press; all rights reserved; doi: 10.1101/cshperspect.a005017

Cite this article as Cold Spring Harb Perspect Biol 2011;3:a005017 
TGF- $\beta$ activation appears to be the critical checkpoint controlling TGF- $\beta$ 's actions, and has been intensely investigated. It now appears that actions of the ECM and of integrins are central to this process, at least for two of the TGF- $\beta$ isoforms. Experimental models of Marfan Syndrome (MFS) and related disorders are helping to show how the ECM precisely controls the amount of TGF- $\beta$ available for activation. Other work has shown that RGD-binding integrins, in particular $\alpha v \beta 6$ and $\alpha v \beta 8$, directly bind and activate latent TGF- $\beta$. In this article, we describe the components of this unusual system.

\section{CROSS TALK BETWEEN INTEGRINS AND GROWTH FACTORS}

Integrins are transmembrane receptors that form cell-cell and cell-matrix adhesions. Each of the 24 integrins in mammals is a heterodimer composed of one of $18 \alpha$ subunits and one of eight $\beta$ subunits. Subgroups of integrins are defined by binding to collagens, laminins, or RGD amino acid sequences, or by being expressed on leukocytes. Integrin structure and function are discussed elsewhere in this collection and in several reviews (Hynes 2002; Luo et al. 2007; Askari et al. 2009; Geiger et al. 2009; Campbell and Humphries 2011; Wickstrom et al. 2011; Geiger and Yamada 2011).

Integrins are not classic signaling receptors in that they possess no enzymatic activity. Integrin signaling depends on the allosteric behavior of the receptors, their ability to concentrate into adhesion zones, and the recruitment to these zones of numerous other "adhesome" components to form complex integrin-based cell adhesions (Zaidel-Bar et al. 2007; Zaidel-Bar and Geiger 2010). Many adhesome components are enzymes that interact with classic signaling pathways. Integrin signaling and function are heavily dependent on cross talk with other signaling pathways, especially growth factor (GF) signaling pathways (Huveneers and Danen 2009; Streuli and Akhtar 2009; Ivaska and Heino 2010). GF receptor (GFR) signaling can produce interactions at the cytoplasmic tails of integrins, e.g., with talin and kindlins (Shattil et al. 2010), that cause "inside-out" conversion of the integrin to a high affinity binding state; this is important for activation of integrins in platelet and leukocyte adhesion. GFR signaling can alter the suite of integrins expressed by cells (Fig. 1A). For example, TGF- $\beta$ signaling up-regulates expression of $\alpha v \beta 3, \alpha v \beta 5$, av $\beta 6$, and several $\beta 1$ integrins (Heino and Massague 1989; Heino et al. 1989; Ignotz et al. 1989; Sheppard et al. 1992; Zambruno et al. 1995). Conversely, integrins indirectly regulate GFR function because both GFRs and molecules that modulate GFR function are present in cell adhesions. In addition, integrins coopt GFR signaling pathways by directly acting on downstream components of the pathways via enzymatic actions of proteins recruited to integrin cytoplasmic tails. Finally, a different form of cross talk involves integrins interacting with extracellular GFs (Hutchings et al. 2003; Vlahakis et al. 2007), GF binding proteins (Munger et al. 1998; Ricort 2004), and soluble GFR (Soro et al. 2008).

Among GFs that cross talk with integrins, TGF- $\beta$ stands apart because of the unique ways in which it, the ECM, and integrins interact. First, TGF- $\beta$, in a latent form, is not simply a $\mathrm{GF}$ - it is an integral component of the ECM and a binding target for integrins (Fig. 1C). Second, some RGD-binding integrins interact with the RGD site in latent, matrix-associated TGF- $\beta$ to trigger the activation of the GF-a unique mechanism by which integrins can activate a GF pathway. Third, there is extensive cross talk of a more indirect sort among integrins, ECM, and TGF- $\beta$, centered around TGF- $\beta$ 's mostly stimulatory effects on integrin and ECM expression (Ignotz and Massague 1987; Roberts et al. 1992).

\section{TGF- $\beta$ LATENCY}

There are three TGF- $\beta$ isoforms (TGF- $\beta$ 1-3), encoded by separate genes. The knockouts (Shull et al. 1992; Kaartinen et al. 1995; Sanford et al. 1997; Taya et al. 1999) do not have overlapping phenotypes. The knockout differences are likely caused by different patterns of expression and modes of activation, and the fact that TGF- $\beta 2$ has a lower affinity for the 
A

B

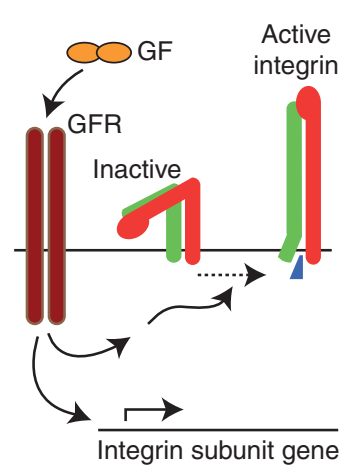

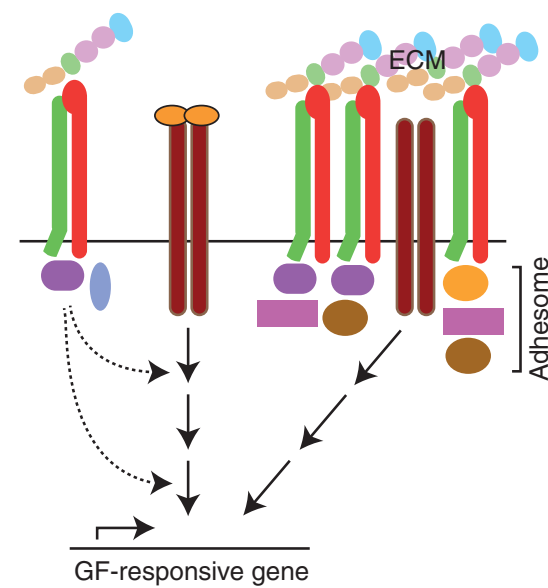

C

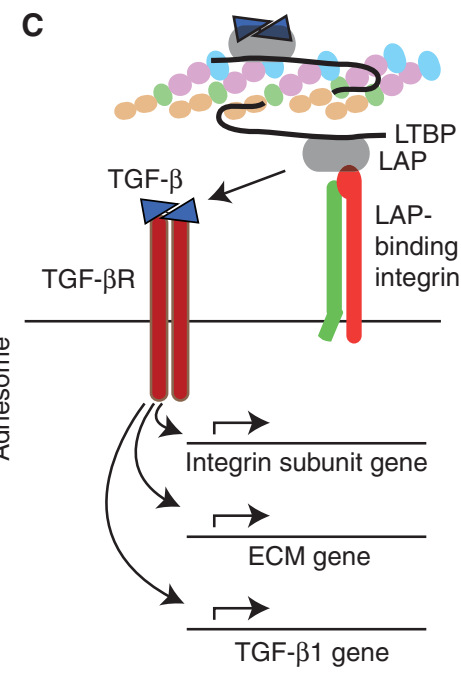

Figure 1. General mechanisms of cross talk between integrins and growth factors. $(A)$ Growth factor signaling can lead to inside-out activation of integrin receptors, and to changes in integrin subunit expression. (B) Integrins affect growth factor receptor signaling. Signals emanating from integrins (e.g., related to enzymatic actions of adhesome components or effects of actin cytoskeleton) can act on downstream components of growth factor receptor pathways (left). Growth factor receptors located within integrin-dependent adhesion zones can signal independent of ligand (right). (C) TGF- $\beta$ is noncovalently associated with its propeptide, LAP, which is covalently associated with LTBP. LTBP is a component of the ECM. TGF- $\beta$ can be released from LAP on binding of LAP by a LAP-binding integrin and can then initiate signaling via TGF- $\beta$ receptors. TGF- $\beta$ signaling has critical effects on expression of genes encoding integrin subunits, ECM components, and the TGF- $\beta 1$ isoform. Abbreviations: GF, growth factor; GFR, GF receptor; LAP, latency-associated peptide; LTBP, latent TGF- $\beta$ binding protein.

TGF- $\beta$ type II receptor and is more dependent on betaglycan (Lopez-Casillas et al. 1993) for signaling.

Each TGF- $\beta$ gene encodes a preproprotein sequence consisting of a signal peptide, a propeptide (predicted $\mathrm{MW} \sim 30 \mathrm{kDa}$ ) that ends with a proprotein convertase (PPC) cleavage site (R-X-R/K-R), and the "mature" TGF- $\beta$ sequence (MW $13 \mathrm{kDa}$ ) (see Fig. 2). After translocation into the endoplasmic reticulum (ER), TGF- $\beta$ proprotein monomers form homodimers linked by disulfide bonds (one in the TGF- $\beta$ region, and two or more in the prodomain), forming pro-TGF- $\beta$. In the Golgi, the prodomains undergo glycosylation. LAP carbohydrate includes mannose-6-phosphate(M6P) groups, which interact with M6P receptors; this may be important in latent TGF- $\beta$ activation (Dennis and Rifkin 1991). Also in the Golgi, the PPC furin hydrolyzes the PPC cleavage site, creating separate TGF- $\beta$ and propeptide-derived homodimers. The two homodimers remain noncovalently associated and are secreted. The prodomain-derived homodimer prevents TGF- $\beta$ from binding TGF- $\beta$ receptors and therefore is called latency-associated peptide (LAP).

In some cases, pro-TGF- $\beta$ avoids furin processing before secretion. Pro-TGF- $\beta$ cannot be activated unless it is first processed at the PPC site. Furin cleaves pro-TGF- $\beta$ extracellularly (other proteases, e.g., plasmin, may as well), and emilin1 inhibits extracellular furin cleavage (Zacchigna et al. 2006). Emilin1 is a secreted glycoprotein found in elastic fibers at the elastin/microfibril interface. Emilin1-null mice have increased TGF- $\beta$ signaling in the vasculature, causing hypertension that is reversed on a $T g f b 1^{+/-}$genetic background (Zacchigna et al. 2006).

Another important TGF- $\beta$ processing event in the ER involves the LTBP family (specifically, 
J.S. Munger and D. Sheppard

A

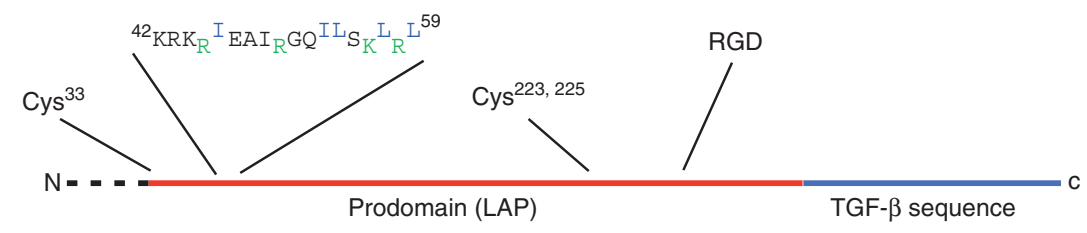

B

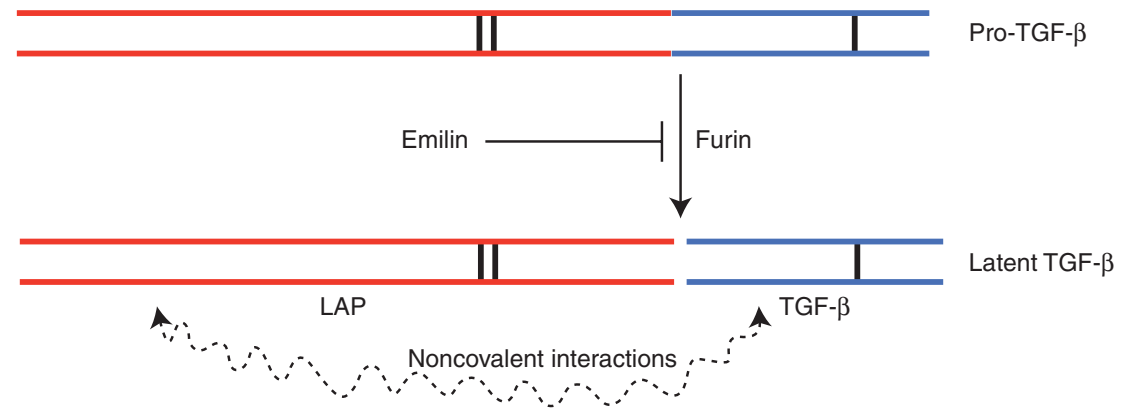

C

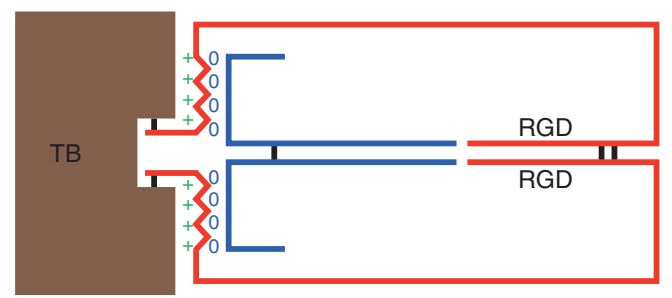

Latent TGF- $\beta$ disulfide-bonded to third TB domain of LTBP

Figure 2. TGF- $\beta 1$ : small and large latent complex forms. (A) Salient features of the sequence encoded by the TGF- $\beta 1$ gene are shown. Dotted line indicates the signal peptide. Cys 33 forms disulfide linkage to LTBPs. Amino acids in the 42-59 region are predicted to form an $\alpha$-helix; basic residues that interact with LTBP are shown in green, and hydrophobic residues that interact with TGF- $\beta 1$ are shown in blue. Cys 223 and Cys 225 form interchain disulfide linkages that are responsible for LAP homodimer formation. The propeptide region (LAP) is shown in red, and the TGF- $\beta$ region in blue. An RGD sequence is present near the carboxyl terminus of the LAP region. (B) Pro-TGF- $\beta$ is shown at top. Vertical black lines denote disulfide bonds. Proteolytic cleavage by furin creates LAP and TGF- $\beta$, which remain noncovalently associated. Emilin blocks extracellular furin cleavage of pro-TGF- $\beta$. $(C)$ Schematic view of latent TGF- $\beta 1$ binding to the third TB domain of LTBP-1, -3 , or -4 . Hydrophobic and basic residues of LAP $\alpha$-helix domain are shown by 0 and + signs, respectively.

LTBP-1, -3, and -4). These 125-160-kDa proteins are associated with ECM microfibrils (Hyytiainen et al. 2004). Disulfide linkages are formed between a cysteine near the amino terminus of each LAP monomer and cysteines in a TGF- $\beta$-binding protein-like (TB) domain of LTBP-1, -3 , and -4 . (A fourth member of the LTBP family, LTBP-2, cannot bind TGF- $\beta$.) Although LTBP-1 and -3 bind all three latent TGF- $\beta$ s, LTBP- 4 only binds TGF- $\beta 1$.
The LAP-TGF- $\beta$ complex is called the small latent complex (SLC), and LTBP-LAP-TGF- $\beta$ the large latent complex (LLC). Some cells secrete SLC (Oida and Weiner 2010), but the LLC form is likely the most common in vivo. LTBP-1, at least in cultured cells, is synthesized in molar excess of SLC and is secreted in free and LAP-bound forms. LTBP-3, on the other hand, is not secreted unless bound to SLC (Chen et al. 2002). 
In addition to rendering TGF- $\beta$ latent, the TGF- $\beta$ prodomain promotes proper TGF- $\beta$ folding and secretion (Gray and Mason 1990). Sites on LAP that interact with TGF- $\beta$ or LTBP have been modeled. Interestingly, an $\alpha$-helix near the amino terminus is responsible for both these interactions. One side of the helix interacts with TGF- $\beta$, the other with LTBP (Fig. 2) (Walton et al. 2010).

The LAPs of TGF- $\beta 1$ and TGF- $\beta 3$ contain RGD sequences near the carboxyl termini. The TGF- $\beta 1$ form of LAP (LAP1) binds the RGD-binding integrins $\alpha v \beta 1, \alpha v \beta 3, \alpha v \beta 5$, $\alpha \mathrm{v} \beta 6, \alpha \mathrm{v} \beta 8$, and $\alpha 8 \beta 1$, and LAP3 binds $\alpha \mathrm{v} \beta 6$ and $\alpha v \beta 8$ (but has not been tested with the other integrins) (Munger et al. 1998; Annes et al. 2002; Lu et al. 2002; Mu et al. 2002; Ludbrook et al. 2003; Araya et al. 2006). These RGD sequences are widely conserved among TGF- $\beta$ genes in chordates, but are not found in other TGF- $\beta$ superfamily members expressed by chordates, nor in nonchordates that express other TGF- $\beta$ superfamily members.

\section{LTBPs AND FIBRILLINS}

The four LTBPs share unique features with the microfibril-associated proteins fibrillin-1, -2, and -3 (see Fig. 3). Because LTBPs and fibrillins interact noncovalently, fibrillins along with LTBPs are critical for proper placement of latent TGF- $\beta$ in the ECM. This idea is supported by evidence that mutations in the fibrillin-1 gene (FBN1) cause MFS and Stiff Skin Syndrome (SSS) because of dysregulated TGF- $\beta$ bioactivity (discussed below).

The hallmark of the LTBP/fibrillin superfamily is the presence of multiple TB domains (three in LTBPs, seven in fibrillins) - these domains are found only in LTBPs and fibrillins (Ramirez and Sakai 2010). TB domains contain eight cysteines in a characteristic arrangement (and are also called 8-cys domains). Some TB domains form disulfide linkages with the amino-terminal cysteines in LAP. LTBPs 1, 3, and 4 have just one TB domain apiece that can function in this way, and these LAP-binding TB domains are distinguished from other TB domains by a spacing of four, rather than two, amino acids between the sixth and seventh cysteines (Saharinen and Keski-Oja 2000). Other TB domains are conjectured to bind ECM (Unsold et al. 2001) but their functions are poorly understood.

LTBP/fibrillin proteins are mostly composed of multiple EGF-like repeats (Ramirez and Sakai 2010), many of which are $\mathrm{Ca}^{+2}$ binding (see Fig. 3). The presence of $\mathrm{Ca}^{+2}$ in calcium-binding EGF-like (cbEGF) domains produces a rigid, rod-like structure that is more resistant to proteolysis. LTBPs and fibrillins also contain 1-2 "hybrid" domains (with features of both EGF-like and TB domains), as well as variable numbers of internal prolinerich domains (fibrillin-2 has, instead, a glycine-rich domain, and fibrillin-3 a domain rich in both proline and glycine).

LTBP-1, LTBP-2 and all three fibrillins have 1-2 RGD sequences. The LTBP RGD sequences have not been shown to act as integrin-binding sites. However, the RGD in fibrillin-1 binds $\alpha 5 \beta 1, \alpha v \beta 3$, and $\alpha v \beta 6$ integrins (Jovanovic et al. 2008). This RGD is located in fibrillin-1's fourth TB domain (TB4), and recombinant TB4 flanked by adjacent cbEGF domains 22 and 23 has been crystallized. These data show that the RGD sequence extends from the body of TB4 on a flexible loop arising from a $\beta$-hairpin, well positioned for interaction with integrins.

LTBPs are synthesized in structurally distinct forms (Hyytiainen et al. 2004). LTBP-1, for example, is transcribed from either of two promoters, leading to "short" and "long" forms, the latter with additional amino-terminal amino acids, designated LTBP-1S and LTBP$1 \mathrm{~L}$, respectively. The amino-terminal region of LTBP-1 appears mainly responsible for attachment to the ECM in cell culture experiments, and LTBP-1L associates more readily with ECM than does LTBP-1S. Also, there are several splice variants of LTBP-1. Variant LTBP $1 \Delta 53$, for example, lacks part of the proline-rich, protease-sensitive and heparin-binding "hinge" region; variant LTBP $1 \Delta 41$ lacks the 12 th EGFlike repeat. One of the LTBP-3 variants (LTBP3B) lacks its last TB domain (which does not bind LAP). LTBP-4, like LTBP-1, has forms with varying amino-terminal extensions. 
J.S. Munger and D. Sheppard
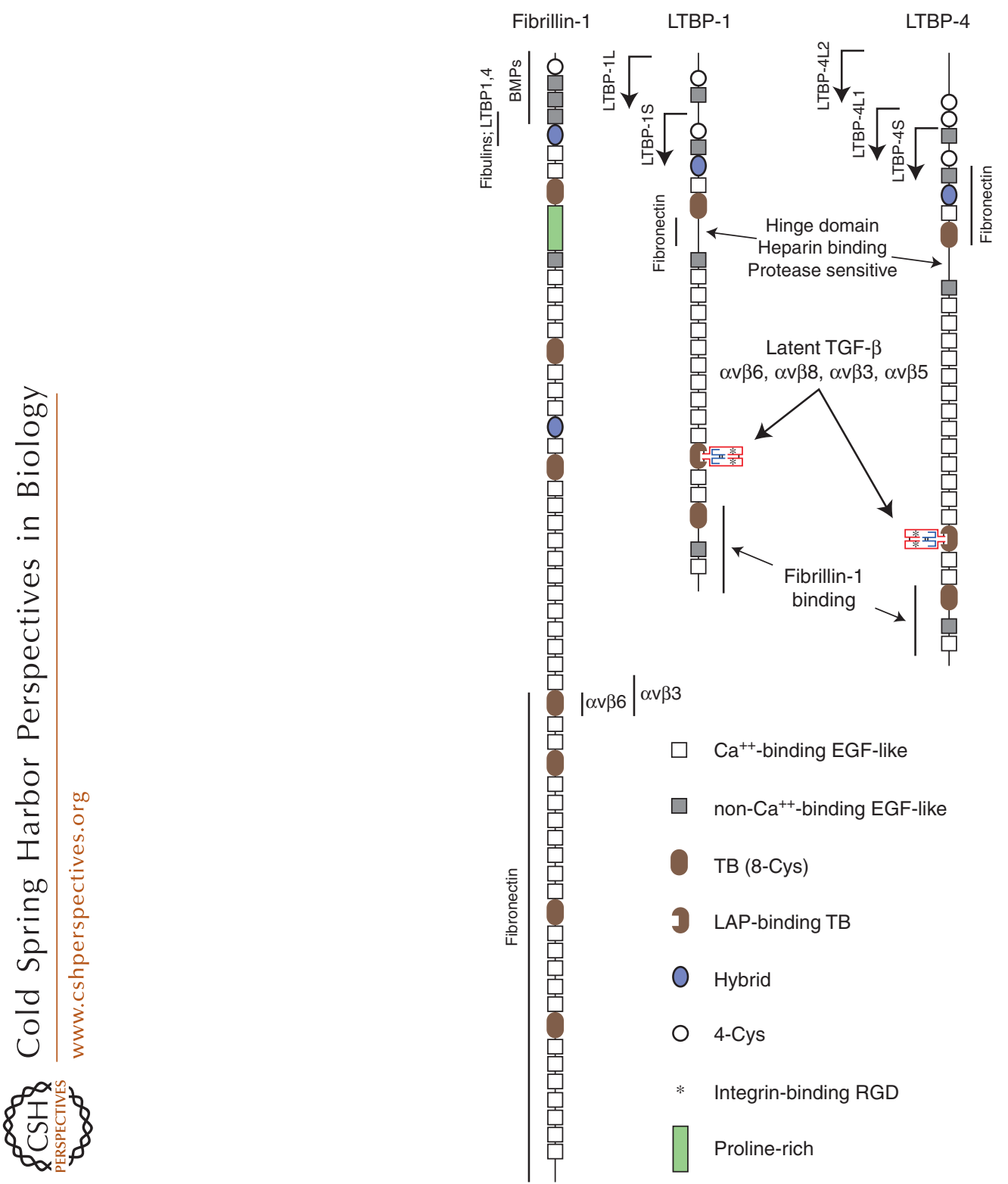

Figure 3. Fibrillin-1, LTBP-1, and LTBP-4 structures. Alternative amino termini of LTBP-1 and -4 are indicated by arrows. Binding sites for specific proteins are shown.

Other LTBP-4 variants include those lacking one or two EGF-like domains, and one (LTBP $4 \Delta$ Cys- ${ }^{3 \text { rd }}$ ) lacking the TB domain responsible for LAP binding. Differences in the use of these variants may provide a means to fine-tune the amount and accessibility of latent TGF- $\beta$ in the ECM.

\section{FIBRILLIN ASSEMBLIES AND THEIR INSTRUCTIVE ROLES}

Ten-nm microfibrils were initially described in and around amorphous elastin and were later found to exist independent of elastin as well. These fibers were shown by Sakai et al. to be 
composed mainly of fibrillin. Fibrillin exists in three isoforms (fibrillin-1, -2, and -3) encoded by separate genes. The ultrastructural appearance of microfibrils suggests they are important structural components of the ECM. However, it is increasingly evident that fibrillin assemblies, through their interaction with LLC and other GFs, perform what Ramirez, Sakai, Rifkin, and Dietz have termed an "instructive" role by presenting GFs to cells in the correct amounts, places and times (Ramirez et al. 2007; Ramirez and Sakai 2010).

Fibrillin microfibrils are string-like structures containing distinct bead-like shapes. The beads are separated by about $50-150 \mathrm{~nm}$ depending on the source of the fibril and how it was isolated. Sakai and colleagues, using epitope-specific antibodies, showed that the beads contain amino and carboxyl termini of fibrillins, indicating that the fibrillin molecules are arranged in a head-to-tail manner (Reinhardt et al. 1996). Disulfide bond formation between fibrillin molecules is required for fibril formation. Also, microfibril formation depends on the presence of fibronectin fibers, which are assembled on cell surfaces in an integrindependent manner. However, other details of the process such as the roles of the amino and carboxyl termini in self-assembly and the role of processing by furin-type proteases, remain unsettled. Schemes of organization that could account for the EM observations, involving different types of staggering of fibrillin molecules among themselves and possible folding or "pleating" of the fibrillin molecules, have been proposed, but this issue remains unsettled (Ramirez and Sakai 2010).

Fibrillin-1 also is produced by epithelial cells in a nonfibrillar form deposited in the lamina densa of basement membranes (Dzamba et al. 2001). The epithelial cells in these studies secreted fibrillin-1 into the cell layer, but secreted fibrillin-2 into the medium, indicating that the cells can discriminate between these similar proteins. It is not known to what extent fibrillar and nonfibrillar assemblies of fibrillin-1 differ in their "instructive" functions. Sakai and colleagues make the interesting point that fibrillin functions dependent on polymerized fibrillin may be susceptible to dominantnegative mutations that affect the polymerized structure, as in MFS, but the same mutations may not be dominant-negative for functions related to nonfibrillar fibrillin.

LTBPs associate with fibrillin assemblies, for example in perichondrium and in cultures of osteoblasts (Dallas et al. 2000; Isogai et al. 2003). A host of other proteins also associate with fibrillin, e.g., fibulins, microfibril-associated glycoproteins (MAGP-1 and -2), perlecan, versican, and emilin1 (Ono et al. 2009). Emilin1 modulates extracellular pro-TGF- $\beta$ processing, as noted above, and is a ligand for integrin $\alpha 4 \beta 1$ (Spessotto et al. 2003). Biglycan and decorin are proteoglycans that inhibit active TGF- $\beta$, and they associate with other components of elastic fibers in close proximity to fibrillin and may regulate fibrillin-1 expression (Trask et al. 2000; Reinboth et al. 2002; Schaefer et al. 2004).

Experiments using multiday cultures of normal and fibrillin-1-null dermal fibroblasts show that LTBP-1 and LTBP-4 incorporation into ECM requires fibrillin-1 (Ono et al. 2009). Other experiments show that in early cultures, LTBP-1 is colocalized with fibronectin and fibrillin-1, whereas in longer-term cultures LTBP-1 dissociates from fibronectin but remains colocalized with fibrillin-1 (Hyytiainen et al. 2004). Matrix incorporation of LTBP-2 is also dependent on a fibrillin-1 network (Vehvilainen et al. 2009).

The protein-protein interaction sites between LTBPs and fibrillins have been determined using recombinant protein fragments and surface plasmon resonance (SPR) (Ono et al. 2009). LTBP-4 binds to the first hybrid domain of fibrillin-1 (Hyb1), whereas LTBP-1 binds to a site involving both $\mathrm{Hyb} 1$ and adjacent EGF-like domains 2 and 3. Previous studies showed that LTBP-1's carboxyl terminus binds to fibrillin-1, whereas the amino terminus of LTBPs is mainly responsible for binding ECM made in cell culture, generally, and fibronectin, specifically (Kantola et al. 2008). Under experimental conditions, competition for binding sites occurs. For example, fibulin-2, -4 , and -5 compete with LTBP-1 for binding to fibrillin-1. 
Also, LTBP-2 (which cannot link to SLC) binds the amino terminus of fibrillin- 1 and competes for this binding with LTBP-1. This raises the possibility that the amounts of latent TGF- $\beta$ associated with microfibrils might be affected by physiological competition with fibulins and LTBP-2.

Proteases (e.g., plasmin, chymase, neutrophil elastase, and MMPs) can cleave LTBP-1 in the "hinge" region near the amino terminus and release LLC from ECM formed by cultured cells. The carboxyl terminus of LTBP-1 also contains a protease-sensitive region (Unsold et al. 2001). Thus, proteases may be able to release a truncated form of LLC from associations with fibronectin or other components of ECM that bind LTBP's amino terminus, and from fibrillin-1 interacting at LTBP's carboxyl terminus. A model of muscular dystrophy suggests proteolytic LLC release may be physiologically important (see below).

TGF- $\beta$ belongs to a large superfamily of GFs, all with prodomains loosely related to LAP. In mammals, this TGF- $\beta$ superfamily includes BMPs, activins/inhibins, GDFs, nodal, and myostatin. In general, the prodomains of these superfamily members do not cause latency of the GFs (myostatin is an exception), but many associate noncovalently with their cognate GF after proteolytic processing.

Notably, fibrillin- 1 and -2 can bind propeptides of multiple members of the TGF- $\beta$ superfamily directly (specifically, BMP2, $-4,-7,-10$, and GDF5, as determined by SPR) (Sengle et al. 2008). Prodomain binding to fibrillins is noncovalent and occurs near the amino terminus of fibrillin in a region that includes Hyb1 and the third and fourth EGF-like domains. By SPR, the dissociation constants are about $20 \mathrm{nM}$. It is not reported whether prodomain binding competes with LTBP, or other molecules, for binding to fibrillin.

BMP4 colocalizes with fibrillin-1 in several tissues, suggesting that BMP-fibrillin interactions are physiologically relevant. Nistala et al. analyzed bone formation in mice lacking either filbrillin-1 or -2 and found that fibrillin- 1 and -2 differentially control both TGF- $\beta$ and BMP bioavailability (Nistala et al. 2010). Fbn2 $2^{-/-}$ mice have reduced bone mass caused by increased TGF- $\beta$ activation and signaling, which reduces expression of a transcriptional regulator of osteoblast differentiation (osterix). Fbn $1^{-/-}$ mice also fail to restrain TGF- $\beta$ activation by osteoclasts; however, lack of fibrillin-1 also leads to enhanced BMP bioavailability and signaling that promotes osterix expression, overriding the inhibitory effect of TGF- $\beta$ signaling. Interestingly, $\mathrm{Fbn2}^{-/-}$mice have reduced BMP signaling in the distal developing limb (Arteaga-Solis et al. 2001), in contrast to increased BMP signaling in growing bones in $\mathrm{Fbn1}^{-/-}$ mice, indicating that fibrillins can control BMP effects positively or negatively depending on the cellular context.

\section{MARFAN SYNDROME AND RELATED DISORDERS}

MFS is an autosomal dominant connective tissue disease caused by mutations in the gene encoding fibrillin-1 (FBN1). Manifestations of the disease include skeletal deformities, joint laxity, lens dislocation, myxomatous degeneration of aortic and mitral valves, pulmonary emphysema, and aortic aneurysm. Over 550 FBN1 mutations causing MFS have been described; most common are missense mutations in EGF domains or mutations that cause premature termination codons (Nijbroek et al. 1995).

Elastin fibers in MFS tissues are fragmented and disorganized, leading to the hypothesis that MFS is essentially a structural problem. Ramirez and colleagues developed mouse models of MFS that argued against this hypothesis (Pereira et al. 1997; 1999). One mutant Fbnl allele, a central deletion designated $\mathrm{mg} \Delta$, causes aortic dissection and death by 10 days after birth. A second, designated $\mathrm{mgR}$, is a hypomorphic Fbn1 mutation that causes later onset vascular disease in homozygous mutant mice. These mouse models of MFS showed that fibrillin-1 is required not for elastogenesis but for tissue homeostasis.

Dietz and colleagues showed that the homeostatic factor is TGF- $\beta$. For example, mice homozygous for the $\mathrm{mg} \Delta \mathrm{Fbn} 1$ mutant allele develop enlarged airspaces by postnatal day 9 , 
accompanied by increased TGF- $\beta$ signaling, increased TGF- $\beta$ protein, and decreased LAP in the lung (Neptune et al. 2003). The enlarged airspaces are caused by developmental failure in alveolar septation, rather than destruction. An inhibitory anti-TGF- $\beta$ antibody reversed the phenotype.

Essentially, the same story-that pathologic changes in MFS mice are associated with increased TGF- $\beta$ signaling and reversed by TGF- $\beta$ inhibition-applies to other mouse MFS phenotypes (myxomatous changes in mitral valves, muscle loss, and aortic aneurysm) ( $\mathrm{Ng}$ et al. 2004; Habashi et al. 2006; Cohn et al. 2007). Further support of the TGF- $\beta$ model for MFS comes from Loews-Dietz Syndrome (LDS), which has major overlaps with MFS and is caused by mutations in TGF- $\beta$ type I or II receptors (Loeys et al. 2006). Most mutations are missense mutations in the serine-threonine kinase domains. Paradoxically, heterozygous expression of these mutant receptors enhances TGF- $\beta$ signaling, and aortic tissue from LDS individuals shows increased TGF- $\beta$ signaling.

Stiff Skin syndrome (SSS), an autosomal dominant disorder, is caused by mutations affecting the RGD-containing TB4 domain of fibrillin-1 (Loeys et al. 2010). SSS is characterized by thickened, hard skin. The TB4 mutations cause impaired interactions between the TB4 RGD and integrins $\alpha v \beta 3$ and $\alpha v \beta 6$. The skin from these individuals has increased fibrillin- 1 and elastin, which are arranged aberrantly in the dermis and dermal-epidermal junction. There is increased TGF- $\beta$ signaling in the dermis, and greatly increased amounts of LTBP-4. It remains unclear to what extent SSS is caused by aberrant TGF- $\beta$ signaling versus altered formation of fibrillin assemblies because of impaired fibrillin-1-integrin interactions. Aortic Tortuosity syndrome (ATS) may also be caused by altered ECM regulation of TGF- $\beta$ (Coucke et al. 2006). Mutations in the glucose transporter GLUT10 cause this disorder, and vascular smooth muscle cells from these patients make markedly less decorin, an inhibitor of TGF- $\beta$ (see above).

Dietz and coworkers propose that excessive TGF- $\beta$ activation in MFS is caused by inadequate LLC sequestration, whereas excessive TGF- $\beta$ activation in SSS occurs because of an increased concentration of LLC. In other words, fibrillin-LTBP interactions allow normal ECM to act as a sink for TGF- $\beta$, reducing TGF- $\beta$ 's bioavailability. Homeostasis fails if the sink is bypassed or overfilled.

\section{LTBP MUTATIONS}

Mice lacking the long form of LTBP-1L, the main form produced during development, die at birth from defects in cardiac outflow tract septation and remodeling of the great vessels, associated with decreased TGF- $\beta$ signaling (Todorovic et al. 2007). Surprisingly, however, mice lacking both LTBP-1L and LTBP-1S appear to be normal aside from minor changes in the frontal bones of the skull. Following bile duct ligation, however, these mice develop less hepatic fibrosis than do wild-type mice, consistent with reduced TGF- $\beta$ signaling under these conditions (Drews et al. 2008). Ltbp $3^{-/-}$mice have premature closure of synchondroses, osteosclerosis and osteoarthritis, similar to mice with impaired TGF- $\beta$ signaling (Dabovic et al. 2002); they also have impaired lung alveolar septation with evidence of reduced TGF- $\beta$ signaling (Colarossi et al. 2005). Mice with a hypomorphic $L t b p 4$ mutation have severe early developmental lung emphysema and develop colorectal cancer (Sterner-Kock et al. 2002). Elastin fibers in the lungs are fragmented and condensed, and the lungs, colon, and heart have no extracellular TGF- $\beta 1$. Epithelial cells have decreased TGF- $\beta$ signaling.

These data indicate that, in general, LTBPs positively regulate TGF- $\beta$ bioavailability in tissue-specific ways, probably with significant functional overlap given the absence of any overlap with TGF- $\beta$ isoform knockouts. The apparent reduced TGF- $\beta$ signaling in LTBP knockouts seems at odds with the MFS models because both should have impaired ECM localization of TGF- $\beta$, yet TGF- $\beta$ signaling is affected in opposite ways. This may relate to non-TGF- $\beta$ functions of the proteins or differences in how various latent forms of TGF- $\beta$ are activated. 
Dietz and colleagues showed that TGF- $\beta$ inhibition improves muscle function in a model of Duchenne muscular dystrophy (Cohn et al. 2007). In a screen for genetic modifiers in another mouse model of muscular dystrophy, Heydemann et al. identified a 36bp insertion/ deletion polymorphism in exon 12 of Ltbp4 (Heydemann et al. 2009) that maps to the proline-rich, protease-sensitive region of LTBP4. The deletion $\left(L t b p 4^{\Delta 36}\right)$ occurs in the more severely affected strain. Homozygosity of the $L t b p 4^{\Delta 36}$ allele causes increased TGF- $\beta$ signaling in muscle. The deletion of these 12 amino acids renders LTBP-4 more sensitive to proteolytic digestion. Thus, both loss of ECM sequestration of LLC (in MFS) and increased ability to release LLC from ECM (in $L t b p 4^{\Delta 36}$ mice) appear to allow more soluble LLC and ultimately more TGF- $\beta$ signaling.

\section{TGF- $\beta$ ACTIVATION BY RGD-BINDING INTEGRINS}

Many mechanisms of TGF- $\beta$ activation have been proposed (Annes et al. 2003), as listed in Table 1. In some cases, the techniques cannot distinguish between true activation and enhanced activation. For example, plasmin is proposed to cleave LAP, releasing active TGF- $\beta$, but plasmin also processes pro-TGF- $\beta$ and releases LLC from the ECM by proteolysis of the proline-rich domain of LTBP, events that might enhance another activation process.

It is striking that most putative TGF- $\beta$ activators are functionally linked to the ECM. Particularly strong evidence indicates that the integrins $\alpha v \beta 6$ and $\alpha v \beta 8$ are physiologically direct activators of TGF- $\beta 1$ and TGF- $\beta 3$. This evidence is mirrored by strong overlaps among phenotypes of TGF- $\beta$-null and integrin-null mice, as shown in Table 2.

$\alpha v \beta 6$ is an epithelium-restricted integrin that is up-regulated after epithelial injury. Mice with a null mutation of the gene encoding the $\beta 6$ integrin subunit (Itgb6 ${ }^{-/-}$) lack the $\alpha \mathrm{v} \beta 6$ integrin. Itgb6 ${ }^{-/-}$mice develop lymphocytic lung inflammation reminiscent of inflammation in $\mathrm{Tg} f \mathrm{bl}^{-/-}$mice (Huang et al. 1996). Binding and cell adhesion studies showed that $\alpha v \beta 6$ interacts with LAP1 and LAP3. Coculture experiments with $\alpha \mathrm{v} \beta 6$-expressing cells and TGF- $\beta$-responsive reporter cells revealed an $\alpha v \beta 6$-dependent, protease-independent activation process in which active TGF- $\beta$ remains localized close to the cell surface (Munger et al. 1999; Annes et al. 2002).

Activation requires the cytoplasmic domain of $\beta 6$ and a functional actin cytoskeleton, suggesting that force generated by the actin cytoskeleton and transmitted via $\alpha v \beta 6$ to LAP is required for activation. This "traction" hypothesis implies that latent TGF- $\beta$ must be immobilized so it can be pulled on. Therefore, more support for the traction model comes from the finding that LAP- and ECM-binding components of LTBP-1 are required for activation (Annes et al. 2004). Also relevant is the observation that protease-activated receptor-1 (PAR1) signaling enhances $\alpha v \beta 6$-mediated TGF- $\beta$ activation (Jenkins et al. 2006). Rho A and Rho kinase, which mediate PAR1 effects on actin reorganization, are required for the PAR1 effect on $\alpha v \beta 6$-mediated activation. Shear forces activate LLC but not SLC in solution; this may be a solution-phase equivalent of the traction mechanism (Ahamed et al. 2008).

In contrast to the MFS models, in which alterations in TGF- $\beta$ signaling lead to profound connective tissue changes, $\operatorname{Itg} 6^{-/-}$mice display no connective tissue disorder except for gradual onset of emphysema (Morris et al. 2003). This is caused by lack of TGF- $\beta$ mediated inhibition of MMP12 expression in alveolar macrophages and resultant elastin degradation. However, Itgb6 $6^{-/-}$mice are protected from experimental fibrosis and lung injury associated with increased TGF- $\beta$ signaling (Pittet et al. 2001; Puthawala et al. 2008).

Nishimura and colleagues showed that $\alpha v \beta 8$ activates TGF- $\beta 1$ and -3 (Mu et al. 2002; Araya et al. 2006). In contrast to the $\alpha v \beta 6$ results, $\alpha v \beta 8$-expressing cells release active TGF- $\beta$ into the medium and must coexpress MT1-MMP to achieve activation. MT1-MMP and $\alpha v \beta 8$ colocalize in cells adhering to LAP1, and MT1-MMP cleaves near LAP's amino terminus (MT1-MMP has also been shown to cleave LTBP-1 and release LLC from the ECM, 
Table 1. Putative physiologic activators of TGF- $\beta$

\begin{tabular}{|c|c|c|}
\hline Activator & Proposed mechanism & Knockout \\
\hline Plasmin & Cleavage of LAP & No TRP \\
\hline MMP-9 & $\begin{array}{l}\text { Cleavage of LAP; most effective for } \\
\text { TGF- } \beta 2 \text {; CD44 localizes MMP-9 to } \\
\text { cell surface }\end{array}$ & No TRP \\
\hline $\begin{array}{l}\text { Osteoclast lysosomal } \\
\text { proteases }\end{array}$ & Cleavage of LAP & - \\
\hline MMP-13 & Cleavage of LAP & Reduced liver fibrosis \\
\hline Thrombospondin-1 & $\begin{array}{l}\text { LAP conformation change induced by } \\
\text { TSP } 1 \text { binding }\end{array}$ & $\begin{array}{l}\text { Lung inflammation } \\
\text { TSP1-derived peptide that activates } \\
\text { TGF- } \beta \text { reverses some } \mathrm{Tgfb} 1^{-/-} \\
\text {abnormalities }\end{array}$ \\
\hline$\alpha v \beta 6$ & $\begin{array}{l}\text { Activation of ECM-bound latent } \\
\text { TGF- } \beta 1 / 3 \text { by traction }\end{array}$ & $\begin{array}{l}\text { Itgb6 } 6^{-/-} \text {: Lung inflammation, reduced } \\
\text { Langerhans cells, emphysema, reduced } \\
\text { fibrosis }\end{array}$ \\
\hline$\alpha v \beta 8$, MT1-MMP & $\begin{array}{l}\alpha \mathrm{v} \beta 8 \text { binds LAP in latent TGF- } \beta 1 / 3 \text {, } \\
\text { recruited MT1-MMP cleaves LAP }\end{array}$ & $\begin{array}{l}\text { Itgb8 }{ }^{-/-} \text {: vasculogenesis failure, brain } \\
\text { hemorrhage } \\
\operatorname{Itgav}^{-/-}: \text {same, plus cleft palate } \\
M m p 14^{-/-}: \text {no clear TRP }\end{array}$ \\
\hline$\alpha v \beta 3, \alpha v \beta 5$ & $\begin{array}{l}\text { Activation of ECM-bound latent } \\
\text { TGF- } \beta 1 \text { by traction }\end{array}$ & $\operatorname{Itgb3} 3^{-1-}, \operatorname{Itgb5} 5^{-/-}:$no TRP \\
\hline ROS & Oxidation of Met 253 of TGF- $\beta 1$ LAP & - \\
\hline Shear force & $\begin{array}{l}\text { Shear-induced thiol-disulfide exchange; } \\
\text { LTBP (LLC form) required }\end{array}$ & - \\
\hline
\end{tabular}

ROS, reactive oxygen species; TRP, TGF- $\beta$-related phenotype.

Plasmin data from Lyons et al. (1990) and Flaumenhaft et al. (1992); osteoclast data from Oursler (1994); MMP-13 data from Uchinami et al. (2006) and Nannuru et al. (2010); TSP1 data from Crawford et al. (1998); Itgav ${ }^{-1}$ - data from Bader et al. (1998); $\alpha v \beta 6$ data from Munger et al. (1999); $\alpha v \beta 8$, MT1-MMP data from Mu et al. (2002); $\alpha v \beta 3$, $\alpha v \beta 5$ data from Wipff et al. (2007); ROS data from Jobling et al. (2006); shear force data from Ahamed et al. (2008).

but it is not known if this action is also important in $\alpha \mathrm{v} \beta 8$-mediated activation) (Tatti et al. 2008). $\beta 8$ has a cytoplasmic domain that is not similar to those of other $\beta$ subunits. $\alpha \mathrm{v} \beta 8$ is not known to interact with the actin cytoskeleton, and cells expressing a $\beta 8$ mutant protein lacking the cytoplasmic tail still activate TGF- $\beta$. Therefore, $\alpha v \beta 8$-mediated activation appears to be independent of actin cytoskeletal traction, and the role of the integrin is to present latent TGF- $\beta$ to a membrane-bound protease.

\section{REDUNDANCY AMONG TGF- $\beta$ ISOFORMS AND INTEGRIN ACTIVATORS}

Mice with a knock-in mutation of $T g f b 1$ that alters the RGD binding site to a nonfunctional RGE sequence ( $T g f b 1^{R G E / R G E}$ mice) fully reproduce the phenotype of $T g f b 1^{-/-}$mice, indicating that RGD-binding integrins are required for TGF- $\beta 1$ activation during development and early life (Yang et al. 2007). Among the 8 RGD-binding integrins, only $\alpha v \beta 6$ and $\alpha v \beta 8$ appear to be required for TGF- $\beta 1$ activation at this stage, at least in regard to phenotypes in TGF- $\beta 1$-deficient mice. Specifically, $\operatorname{Itg} b 8^{-/-}$mice treated perinatally with an antibody that blocks $\alpha v \beta 6$ develop the immunological features of $T g f b 1^{-/-}$mice (severe multiorgan inflammation and absence of Langerhans cells), and $\operatorname{Itg} b 6^{-/-} ; \operatorname{Itg} b 8^{-/-}$mice have a high incidence of cleft palate, the main finding in TGF- $\beta 3$-null mice (Aluwihare et al. 2009). Conversely, $T g f b 1^{R G E / R G E} ;{\mathrm{Tg} f b 3^{-/-}}^{-1}$ mice are all born with brain hemorrhage, the only phenotype in mice lacking $\alpha \mathrm{v} \beta 8$ that is not seen in mice lacking just TGF- $\beta 1$ or TGF- $\beta 3$ (Mu et al. 2008). Thus, $\alpha v \beta 6$ and 
J.S. Munger and D. Sheppard

Table 2. Comparison of phenotypes of mice with TGF- $\beta$ gene mutations and mice lacking integrin activators of TGF- $\beta$

\begin{tabular}{|c|c|}
\hline Mouse & Phenotype \\
\hline$T g f b 1^{-/-}$ & $\begin{array}{l}\text { Variable (strain-dependent) embryonic lethality because of vasculogenesis failure; } \\
\text { lethal multiorgan lymphocyte-mediated inflammation and lack of Langerhans } \\
\text { cells in remainder. }\end{array}$ \\
\hline$T g f b 1^{R G E / R G E}$ & Identical to $T g f b 1^{-/-}$, reduced fibrosis in heterozygotes. \\
\hline $\operatorname{Tg} f b 2^{-1-}$ & Embryonic lethality with defects in multiple organ systems. \\
\hline$T g f b 3^{-1-}$ & $\begin{array}{l}\text { Cleft palate caused by failure of fusion of palatal shelves; mild, variable delayed } \\
\text { lung development. }\end{array}$ \\
\hline $\operatorname{Itgav} v^{-/-}$ & $\begin{array}{l}\text { 80\% embryonic lethality because of vasculogenesis failure; brain hemorrhage } \\
\text { and cleft palate in remainder. Note that these mice lack } \alpha \mathrm{v} \beta 1, \alpha \mathrm{v} \beta 3, \alpha \mathrm{v} \beta 5 \text {, } \\
\alpha \mathrm{v} \beta 6 \text {, and } \alpha \mathrm{v} \beta 8 \text { integrins. }\end{array}$ \\
\hline $\operatorname{Itg} b 6^{-/-}$ & $\begin{array}{l}\text { Lymphocyte-predominant lung inflammation, reduced Langerhans cells, } \\
\text { late-onset lung emphysema because of increased MMP-12, reduced fibrosis. }\end{array}$ \\
\hline $\operatorname{Itg} b 8^{-/-}$ & $\begin{array}{l}\text { Variable embryonic lethality because of vasculogenesis failure, CNS hemorrhage, } \\
\text { cleft palate }(\sim 10 \%) \text {; conditional KO in dendritic cells causes mild } \\
\text { inflammation. }\end{array}$ \\
\hline Itgb6 $6^{-/-} \operatorname{Itg} b 8^{-/-}$ & $\begin{array}{l}\text { Individual phenotypes plus high incidence of cleft palate causing early postnatal } \\
\text { death. }\end{array}$ \\
\hline $\begin{array}{l}\text { Itgb } 8^{-/-} \text {treated perinatally } \\
\quad \text { with anti- } \alpha v \beta 6\end{array}$ & Lethal multiorgan lymphocyte-mediated inflammation, lack of Langerhans cells. \\
\hline
\end{tabular}

See text for references.

$\alpha v \beta 8$ are largely responsible for activation of TGF- $\beta 1$ and TGF- $\beta 3$ during development, at least in terms of phenotypes in knockout mice (see Table 2).

\section{$\alpha v \beta 5$ ALSO ACTIVATES LATENT TGF- $\beta 1$}

Wipff et al. (2007) showed that cultures of contractile myofibroblasts generate active TGF- $\beta 1$ using $\alpha v \beta 5$ (mainly) and $\alpha v \beta 3$, although many other experiments have not shown these integrins to activate (Araya et al. 2006). The critical experimental factor that allowed detection of activation by these integrins was the ECM: the cells activated TGF- $\beta$ from myofibroblast-derived ECMs (generated over many days) that were rich in LTBP- 1 and latent TGF- $\beta 1$. In contrast, less-contractile fibroblasts with low expression of $\alpha$-smooth muscle actin ( $\alpha$ SMA) could not activate TGF- $\beta 1$ from these ECMs. Increasing force across the ECM-integrin-actin continuum favored activation: increased cell contractility, stretching of the ECM on silicone membranes, and increased ECM stiffness all increased the amount of active TGF- $\beta$, whereas inhibitors of actin contraction and low ECM stiffness blocked activation.

These results extend the traction model developed for $\alpha v \beta 6$, and are consistent with data that fibroblasts from dermis affected by localized scleroderma, but not from normal dermis, activate TGF- $\beta$ in an $\alpha v \beta 5$-dependent manner (Asano et al. 2006). It appears that ECM, mesenchymal cells and TGF- $\beta$ have selfreinforcing interactions in wound healing. TGF- $\beta$ signaling increases ECM production, and converts fibroblasts to $\alpha$ SMA-positive myofibroblasts; in turn, more abundant ECM (with more LTBP, TGF- $\beta$, and stiffness) and more contractile myofibroblasts expressing $\alpha \mathrm{v} \beta 5$ generate active TGF- $\beta$.

Time-lapse imaging in these experiments shows that the LTBP-1-containing fibers are under significant strain from cell forces (Wipff et al. 2007). This highlights the possibility that force across $\alpha v \beta 5$-LAP1-TGF- $\beta 1-E C M$ may not be the only relevant force. Direct linkages between $\alpha v \beta 5$ and other components of the fibers (such as fibronectin) might induce rearrangements in the fibers that improve the 
bioavailability of the LLC-and perhaps even cause direct activation of TGF- $\beta$ independent of the RGD site in LAP1, perhaps via proteingenerated shear forces analogous to shear in solution. This latter mechanism appears unlikely, but not impossible, because mechanical stretching (using flexible membranes) of the ECM does not activate TGF- $\beta$ in these experiments unless the actin cytoskeleton is also in a contractile state.

\section{ARE THERE OTHER MODES OF TGF- $\beta$ ACTIVATION?}

The phenotypes of $\alpha v \beta 6$ - and/or $\alpha v \beta 8$ deficient mice (Aluwihare et al. 2009) and $T g f b 1^{R G E / R G E}$ mice (Yang et al. 2007) indicate that integrin-mediated TGF- $\beta$ activation is required for developmental events in angiogenesis, the immune system, and the palate. Fibrosis and injury models show that $\alpha v \beta 6$ is needed to activate TGF- $\beta$ on the short time scales of these models.

But while discrete injury and developmental events use specialized integrin activators acting over short periods of time, the same may not be true in long-term ECM homeostasis. The MFS models show that the ECM performs sequestering and dampening functions to prevent excessive TGF- $\beta$ signaling but do not identify the mechanism(s) of TGF- $\beta$ activation. Indeed, the mechanisms involved on longer time scales relevant to ECM homeostasis may be different, perhaps consisting of nonspecific processes such as slow spontaneous release of TGF- $\beta$ from LAP and transfer to other binding sites, or events associated with physiologic ECM breakdown and cellular uptake.

\section{CONCLUDING REMARKS}

The complex, bidirectional interactions between cells and their surrounding extracellular matrices provide opportunities for exquisite regulation of cellular behavior in space and time. It is now clear that much of this regulation occurs in the extracellular space, as the biology of the TGF- $\beta$ family makes abundantly clear. Examination of induced and naturally occurring mutations in integrins that can activate TGF- $\beta$, ECM proteins that regulate TGF- $\beta$ bioavailability and TGF- $\beta$ family members themselves has highlighted the precision required to present the right amount of active TGF- $\beta$ in the right place at the right time. Indeed, similar developmental abnormalities (e.g., pulmonary emphysema) can result from either too much (MFS) or too little (hypomorphic Ltbp4) TGF- $\beta$ activity in the lung during the period of alveolar development.

Despite substantial progress identifying key determinants of developmental regulation of TGF- $\beta$ over the past decade, much remains to be learned about how this process is regulated to maintain normal tissue homeostasis. The relative contributions of specific integrins, ECM components and other, perhaps unidentified, components in control of TGF- $\beta$ activity during the development of chronic organ dysfunction in disease are also largely unexplored. The cell surface proteins (if any) that facilitate activation of latent TGF- $\beta 2$, which does not contain an RGD motif in its LAP, remain to be identified, and the roles (if any) of $\alpha v \beta 5$ - and $\alpha v \beta 3$-mediated TGF- $\beta$ activation in vivo have not been determined. It thus seems likely that efforts to decode the elaborate conversation among integrins, growth factors and the extracellular matrix will continue to be fruitful for the foreseeable future.

\section{REFERENCES}

Ahamed J, Burg N, Yoshinaga K, Janczak CA, Rifkin DB, Coller BS. 2008. In vitro and in vivo evidence for shearinduced activation of latent transforming growth factor- $\beta 1$ (TGF- $\beta 1$ ). Blood 112: 3550-3560.

Aluwihare P, Mu Z, Zhao Z, Yu D, Weinreb PH, Horan GS, Violette SM, Munger JS. 2009. Mice that lack activity of $\alpha v \beta 6$ - and $\alpha v \beta 8$-integrins reproduce the abnormalities of Tgfb1- and Tgfb3-null mice. J Cell Sci 122: 227-232.

Annes JP, Rifkin DB, Munger JS. 2002. The integrin $\alpha \mathrm{V} \beta 6$ binds and activates latent TGFß3. FEBS Lett 511: 65-68.

Annes JP, Munger JS, Rifkin DB. 2003. Making sense of latent TGF- $\beta$ activation. J Cell Sci 116: 217-224.

Annes JP, Chen Y, Munger JS, Rifkin DB. 2004. Integrin $\alpha \mathrm{V} \beta 6$-mediated activation of latent TGF- $\beta$ requires the latent TGF- $\beta$ binding protein-1. J Cell Biol 165: 723-734.

Araya J, Cambier S, Morris A, Finkbeiner W, Nishimura SL. 2006. Integrin-mediated transforming growth factor- $\beta$ 
activation regulates homeostasis of the pulmonary epithelial-mesenchymal trophic Unit. Am J Pathol 169: 405-415.

Arteaga-Solis E, Gayraud B, Lee SY, Shum L, Sakai L, Ramirez F. 2001. Regulation of limb patterning by extracellular microfibrils. J Cell Biol 154: 275-281.

Asano Y, Ihn H, Jinnin M, Mimura Y, Tamaki K. 2006. Involvement of $\alpha v \beta 5$ integrin in the establishment of autocrine TGF- $\beta$ signaling in dermal fibroblasts derived from localized scleroderma. J Invest Dermatol 126: 1761-1769.

Askari JA, Buckley PA, Mould AP, Humphries MJ. 2009. Linking integrin conformation to function. $J$ Cell Sci 122: $165-170$.

Bader BL, Rayburn H, Crowley D, Hynes RO. 1998. Extensive vasculogenesis, angiogenesis and organogenesis precede lethality in mice lacking all $\alpha \mathrm{v}$ integrins. Cell 95: 507-519.

Campbell ID, Humphries MJ. 2011. Integrin structure, activation, and interactions. Cold Spring Harb Perspect Biol 3: a004994.

Chen Y, Dabovic B, Annes JP, Rifkin DB. 2002. Latent TGF- $\beta$ binding protein-3 (LTBP-3) requires binding to TGF- $\beta$ for secretion. FEBS Lett 517: 277-280.

Cohn RD, van Erp C, Habashi JP, Soleimani AA, Klein EC, Lisi MT, Gamradt M, Rhys CM, Holm TM, Loeys BL, et al. 2007. Angiotensin II type 1 receptor blockade attenuates TGF- $\beta$-induced failure of muscle regeneration in multiple myopathic states. Nat Med 13: 204-210.

Colarossi C, Chen Y, Obata H, Jurukovski V, Fontana L, Dabovic B, Rifkin DB. 2005. Lung alveolar septation defects in Ltbp-3-null mice. Am J Pathol 167: 419-428.

Coucke PJ, Willaert A, Wessels MW, Callewaert B, Zoppi N, De Backer J, Fox JE, Mancini GM, Kambouris M, Gardella R, et al. 2006. Mutations in the facilitative glucose transporter GLUT10 alter angiogenesis and cause arterial tortuosity syndrome. Nat Genet 38: 452-457.

Crawford SE, Stellmach V, Murphy-Ullrich JE, Ribeiro SM, Lawler J, Hynes RO, Boivin GP, Bouck N. 1998. Thrombospondin-1 is a major activator of TGF- $\beta 1$ in vivo. Cell 93: 1159-1170.

Dabovic B, Chen Y, Colarossi C, Obata H, Zambuto L, Perle MA, Rifkin DB. 2002. Bone abnormalities in latent TGF- $\beta$ binding protein (Ltbp)-3-null mice indicate a role for Ltbp- 3 in modulating TGF- $\beta$ bioavailability. $J$ Cell Biol 156: 227-232.

Dallas SL, Keene DR, Bruder SP, Saharinen J, Sakai LY, Mundy GR, Bonewald LF. 2000. Role of the latent transforming growth factor $\beta$ binding protein 1 in fibrillincontaining microfibrils in bone cells in vitro and in vivo. J Bone Miner Res 15: 68-81.

de Larco JE, Todaro GJ. 1978. Growth factors from murine sarcoma virus-transformed cells. Proc Natl Acad Sci 75: 4001-4005.

Dennis PA, Rifkin DB. 1991. Cellular activation of latent transforming growth factor $\beta$ requires binding to the cation-independent mannose 6-phosphate/insulin-like growth factor type II receptor. Proc Natl Acad Sci 88: $580-584$.

Drews F, Knobel S, Moser M, Muhlack KG, Mohren S, Stoll C, Bosio A, Gressner AM, Weiskirchen R. 2008.
Disruption of the latent transforming growth factor- $\beta$ binding protein-1 gene causes alteration in facial structure and influences TGF- $\beta$ bioavailability. Biochim Biophys Acta 1783: 34-48.

Dzamba BJ, Keene DR, Isogai Z, Charbonneau NL, Karaman-Jurukovska N, Simon M, Sakai LY. 2001. Assembly of epithelial cell fibrillins. J Invest Dermatol 117: $1612-1620$.

Flaumenhaft R, Abe M, Mignatti P, Rifkin DB. 1992. Basic fibroblast growth factor-induced activation of latent transforming growth factor $\beta$ in endothelial cells: Regulation of plasminogen activator activity. J Cell Biol 118: 901-909.

Geiger B, Spatz JP, Bershadsky AD. 2009. Environmental sensing through focal adhesions. Nat Rev Mol Cell Biol 10: $21-33$.

Geiger B, Yamada KM. 2011. Molecular architecture and function of matrix adhesions. Cold Spring Harb Perspect Biol 3: a005033.

Gray AM, Mason AJ. 1990. Requirement for activin A and transforming growth factor- $\beta 1$ pro-regions in homodimer assembly. Science 247: 1328-1330.

Habashi JP, Judge DP, Holm TM, Cohn RD, Loeys BL, Cooper TK, Myers L, Klein EC, Liu G, Calvi C, et al. 2006. Losartan, an AT1 antagonist, prevents aortic aneurysm in a mouse model of Marfan syndrome. Science 312: $117-121$.

Heino J, Massague J. 1989. Transforming growth factor- $\beta$ switches the pattern of integrins expressed in MG-63 human osteosarcoma cells and causes a selective loss of cell adhesion to laminin. J Biol Chem 264: 21806-21811.

Heino J, Ignotz RA, Hemler ME, Crouse C, Massague J. 1989. Regulation of cell adhesion receptors by transforming growth factor- $\beta$. Concomitant regulation of integrins that share a common $\beta 1$ subunit. J Biol Chem 264: 380-388.

Heydemann A, Ceco E, Lim JE, Hadhazy M, Ryder P, Moran JL, Beier DR, Palmer AA, McNally EM. 2009. Latent TGF- $\beta$-binding protein 4 modifies muscular dystrophy in mice. J Clin Invest 119: 3703-3712.

Huang XZ, Wu JF, Cass D, Erle DJ, Corry D, Young SG, Farese RV, Sheppard D. 1996. Inactivation of the integrin $\beta 6$ subunit gene reveals a role of epithelial integrins in regulating inflammation in the lung and skin. $J$ Cell Biol 133: 921-928.

Hutchings H, Ortega N, Plouet J. 2003. Extracellular matrix-bound vascular endothelial growth factor promotes endothelial cell adhesion, migration, and survival through integrin ligation. FASEB J 17: 1520-1522.

Huveneers S, Danen EH. 2009. Adhesion signaling-crosstalk between integrins, Src and Rho. J Cell Sci 122: 10591069.

Hynes RO. 2002. Integrins: Bidirectional, allosteric signaling machines. Cell 110: 673-687.

Hynes RO. 2009. The extracellular matrix: Not just pretty fibrils. Science 326: 1216-1219.

Hyytiainen M, Penttinen C, Keski-Oja J. 2004. Latent TGF- $\beta$ binding proteins: Extracellular matrix association and roles in TGF- $\beta$ activation. Crit Rev Clin Lab Sci 41: 233-264. 
Ignotz RA, Massague J. 1987. Cell adhesion protein receptors as targets for transforming growth factor- $\beta$ action. Cell 51: 189-197.

Ignotz RA, Heino J, Massague J. 1989. Regulation of cell adhesion receptors by transforming growth factor- $\beta$. Regulation of vitronectin receptor and LFA-1. J Biol Chem 264: 389-392.

Isogai Z, Ono RN, Ushiro S, Keene DR, Chen Y, Mazzieri R, Charbonneau NL, Reinhardt DP, Rifkin DB, Sakai LY. 2003. Latent transforming growth factor $\beta$-binding protein 1 interacts with fibrillin and is a microfibril-associated protein. J Biol Chem 278: 2750-2757.

Ivaska J, Heino J. 2010. Interplay between cell adhesion and growth factor receptors: From the plasma membrane to the endosomes. Cell Tissue Res 339: 111-120.

Jenkins RG, Su X, Su G, Scotton CJ, Camerer E, Laurent GJ Davis GE, Chambers RC, Matthay MA, Sheppard D. 2006. Ligation of protease-activated receptor 1 enhances $\alpha v \beta 6$ integrin-dependent TGF- $\beta$ activation and promotes acute lung injury. J Clin Invest 116: 1606-1614.

Jobling MF, Mott JD, Finnegan MT, Jurukovski V, Erickson AC, Walian PJ, Taylor SE, Ledbetter S, Lawrence CM, Rifkin DB, et al. 2006. Isoform-specific activation of latent transforming growth factor $\beta$ (LTGF- $\beta$ ) by reactive oxygen species. Radiat Res 166: 839-848.

Jovanovic J, Iqbal S, Jensen S, Mardon H, Handford P. 2008. Fibrillin-integrin interactions in health and disease. Biochem Soc Trans 36: 257-262.

Kaartinen V, Voncken JW, Shuler C, Warburton D, Bu D, Heisterkamp N, Groffen J. 1995. Abnormal lung development and cleft palate in mice lacking TGF- $\beta 3$ indicates defects of epithelial-mesenchymal interaction. Nat Genet 11: 415-421.

Kantola AK, Keski-Oja J, Koli K. 2008. Fibronectin and heparin binding domains of latent TGF- $\beta$ binding protein (LTBP)-4 mediate matrix targeting and cell adhesion. Exp Cell Res 314: 2488-2500.

Li MO, Wan YY, Sanjabi S, Robertson AK, Flavell RA. 2006. Transforming growth factor- $\beta$ regulation of immune responses. Annu Rev Immunol 24: 99-146.

Loeys BL, Schwarze U, Holm T, Callewaert BL, Thomas GH, Pannu H, De Backer JF, Oswald GL, Symoens S, Manouvrier $\mathrm{S}$, et al. 2006. Aneurysm syndromes caused by mutations in the TGF- $\beta$ receptor. N Engl J Med 355: 788-798.

Loeys BL, Gerber EE, Riegert-Johnson D, Iqbal S, Whiteman P, McConnell V, Chillakuri CR, Macaya D, Coucke PJ, De Paepe A, et al. 2010. Mutations in fibrillin-1 cause congenital scleroderma: Stiff skin syndrome. Sci Transl Med 2: 23 ra20.

Lopez-Casillas F, Wrana JL, Massague J. 1993. Betaglycan presents ligand to the TGF $\beta$ signaling receptor. Cell 73: 1435-1444.

Lu M, Munger JS, Steadele M, Busald C, Tellier M, Schnapp LM. 2002. Integrin $\alpha 8 \beta 1$ mediates adhesion to LAP-TGFß1. J Cell Sci 115: 4641-4648.

Ludbrook SB, Barry ST, Delves CJ, Horgan CM. 2003. The integrin $\alpha v \beta 3$ is a receptor for the latency-associated peptides of transforming growth factors $\beta 1$ and $\beta 3$. Biochem J 369: 311-318.
Luo BH, Carman CV, Springer TA. 2007. Structural basis of integrin regulation and signaling. Annu Rev Immunol 25: 619-647.

Lyons RM, Gentry LE, Purchio AF, Moses HL. 1990. Mechanism of activation of latent recombinant transforming growth factor $\beta 1$ by plasmin. J Cell Biol 110: 1361-1367.

Morris DG, Huang X, Kaminski N, Wang Y, Shapiro SD, Dolganov G, Glick A, Sheppard D. 2003. Loss of integrin $\alpha v \beta 6$-mediated TGF- $\beta$ activation causes Mmp12dependent emphysema. Nature 422: 169-173.

Mu D, Cambier S, Fjellbirkeland L, Baron JL, Munger JS, Kawakatsu H, Sheppard D, Broaddus VC, Nishimura SL. 2002. The integrin $\alpha v \beta 8$ mediates epithelial homeostasis through MT1-MMP-dependent activation of TGF- $\beta 1$. J Cell Biol 157: 493-507.

Mu Z, Yang Z, Yu D, Zhao Z, Munger JS. 2008. TGFß1 and TGF $\beta 3$ are partially redundant effectors in brain vascular morphogenesis. Mech Dev 125: 508-516.

Munger JS, Harpel JG, Giancotti FG, Rifkin DB. 1998. Interactions between growth factors and integrins: Latent forms of transforming growth factor- $\beta$ are ligands for the integrin $\alpha \mathrm{v} \beta 1$. Mol Biol Cell 9: 2627-2638.

Munger JS, Huang X, Kawakatsu H, Griffiths MJ, Dalton SL, Wu J, Pittet JF, Kaminski N, Garat C, Matthay MA, et al. 1999. The integrin $\alpha v \beta 6$ binds and activates latent TGF $\beta 1$ : A mechanism for regulating pulmonary inflammation and fibrosis. Cell 96: 319-328.

Nannuru KC, Futakuchi M, Varney ML, Vincent TM, Marcusson EG, Singh RK. 2010. Matrix metalloproteinase (MMP)-13 regulates mammary tumor-induced osteolysis by activating MMP9 and transforming growth factor- $\beta$ signaling at the tumor-bone interface. Cancer Res 70: 3494-3504.

Neptune ER, Frischmeyer PA, Arking DE, Myers L, Bunton TE, Gayraud B, Ramirez F, Sakai LY, Dietz HC. 2003. Dysregulation of TGF- $\beta$ activation contributes to pathogenesis in Marfan syndrome. Nat Genet 33: 407-411.

Ng CM, Cheng A, Myers LA, Martinez-Murillo F, Jie C, Bedja D, Gabrielson KL, Hausladen JM, Mecham RP, Judge DP, et al. 2004. TGF- $\beta$-dependent pathogenesis of mitral valve prolapse in a mouse model of Marfan syndrome. J Clin Invest 114: 1586-1592.

Nijbroek G, Sood S, McIntosh I, Francomano CA, Bull E, Pereira L, Ramirez F, Pyeritz RE, Dietz HC. 1995. Fifteen novel FBN1 mutations causing Marfan syndrome detected by heteroduplex analysis of genomic amplicons. Am J Hum Genet 57: 8-21.

Nistala H, Lee-Arteaga S, Smaldone S, Siciliano G, Carta L, Ono RN, Sengle G, Arteaga-Solis E, Levasseur R, Ducy P, et al. 2010. Fibrillin-1 and -2 differentially modulate endogenous TGF- $\beta$ and BMP bioavailability during bone formation. J Cell Biol 190: 1107-1121.

Oida T, Weiner HL. 2010. Overexpression of TGF- $\beta 1$ gene induces cell surface localized glucose-regulated protein 78 -associated latency-associated peptide/TGF- $\beta$. J Immunol 185: 3529-3535.

Ono RN, Sengle G, Charbonneau NL, Carlberg V, Bachinger HP, Sasaki T, Lee-Arteaga S, Zilberberg L, Rifkin DB, Ramirez F, et al. 2009. Latent transforming growth factor $\beta$-binding proteins and fibulins compete for fibrillin- 1 and exhibit exquisite specificities in binding sites. J Biol Chem 284: 16872-16881. 
J.S. Munger and D. Sheppard

Oursler MJ. 1994. Osteoclast synthesis and secretion and activation of latent transforming growth factor $\beta$. J Bone Miner Res 9: 443-452.

Pereira L, Andrikopoulos K, Tian J, Lee SY, Keene DR, Ono R, Reinhardt DP, Sakai LY, Biery NJ, Bunton T, et al. 1997. Targetting of the gene encoding fibrillin-1 recapitulates the vascular aspect of Marfan syndrome. Nat Genet 17: 218-222.

Pereira L, Lee SY, Gayraud B, Andrikopoulos K, Shapiro SD, Bunton T, Biery NJ, Dietz HC, Sakai LY, Ramirez F. 1999. Pathogenetic sequence for aneurysm revealed in mice underexpressing fibrillin-1. Proc Natl Acad Sci 96: 3819-3823.

Pittet JF, Griffiths MJ, Geiser T, Kaminski N, Dalton SL, Huang X, Brown LA, Gotwals PJ, Koteliansky VE, Matthay MA, et al. 2001. TGF- $\beta$ is a critical mediator of acute lung injury. J Clin Invest 107: 1537-1544.

Puthawala K, Hadjiangelis N, Jacoby SC, Bayongan E, Zhao Z, Yang Z, Devitt ML, Horan GS, Weinreb PH, Lukashev $\mathrm{ME}$, et al. 2008. Inhibition of integrin $\alpha \mathrm{v} \beta 6$, an activator of latent transforming growth factor- $\beta$, prevents radiation-induced lung fibrosis. Am J Respir Crit Care Med 177: 82-90.

Ramirez F, Sakai LY. 2010. Biogenesis and function of fibrillin assemblies. Cell Tissue Res 339: 71-82.

Ramirez F, Sakai LY, Rifkin DB, Dietz HC. 2007. Extracellular microfibrils in development and disease. Cell Mol Life Sci 64: 2437-2446.

Reinboth B, Hanssen E, Cleary EG, Gibson MA. 2002. Molecular interactions of biglycan and decorin with elastic fiber components: Biglycan forms a ternary complex with tropoelastin and microfibril-associated glycoprotein 1. J Biol Chem 277: 3950-3957.

Reinhardt DP, Keene DR, Corson GM, Poschl E, Bachinger HP, Gambee JE, Sakai LY. 1996. Fibrillin-1: Organization in microfibrils and structural properties. J Mol Biol 258: $104-116$.

Ricort JM. 2004. Insulin-like growth factor binding protein (IGFBP) signalling. Growth Horm IGF Res 14: 277-286.

Roberts AB, Anzano MA, Lamb LC, Smith JM, Frolik CA, Marquardt H, Todaro GJ, Sporn MB. 1982. Isolation from murine sarcoma cells of novel transforming growth factors potentiated by EGF. Nature 295: 417-419.

Roberts AB, Sporn MB, Assoian RK, Smith JM, Roche NS, Wakefield LM, Heine UI, Liotta LA, Falanga V, Kehrl $\mathrm{JH}$, et al. 1986. Transforming growth factor type $\beta$ : rapid induction of fibrosis and angiogenesis in vivo and stimulation of collagen formation in vitro. Proc Natl Acad Sci 83: 4167-4171.

Roberts AB, McCune BK, Sporn MB. 1992. TGF- $\beta$ : Regulation of extracellular matrix. Kidney Int 41: 557-559.

Saharinen J, Keski-Oja J. 2000. Specific sequence motif of 8 -Cys repeats of TGF- $\beta$ binding proteins, LTBPs, creates a hydrophobic interaction surface for binding of small latent TGF- $\beta$. Mol Biol Cell 11: 2691-2704.

Sanford LP, Ormsby I, Gittenberger-de Groot AC, Sariola H, Friedman R, Boivin GP, Cardell EL, Doetschman T. 1997. TGF $\beta 2$ knockout mice have multiple developmental defects that are non-overlapping with other TGF $\beta$ knockout phenotypes. Development 124: 2659-2670.
Schaefer L, Mihalik D, Babelova A, Krzyzankova M, Grone HJ, Iozzo RV, Young MF, Seidler DG, Lin G, Reinhardt DP, et al. 2004. Regulation of fibrillin-1 by biglycan and decorin is important for tissue preservation in the kidney during pressure-induced injury. Am J Pathol 165: 383-396.

Sengle G, Charbonneau NL, Ono RN, Sasaki T, Alvarez J, Keene DR, Bachinger HP, Sakai LY. 2008. Targeting of bone morphogenetic protein growth factor complexes to fibrillin. J Biol Chem 283: 13874-13888.

Shattil SJ, Kim C, Ginsberg MH. 2010. The final steps of integrin activation: The end game. Nat Rev Mol Cell Biol 11: 288-300.

Sheppard D, Cohen DS, Wang A, Busk M. 1992. Transforming growth factor $\beta$ differentially regulates expression of integrin subunits in guinea pig airway epithelial cells. $J$ Biol Chem 267: 17409-17414.

Shull MM, Ormsby I, Kier AB, Pawlowski S, Diebold RJ, Yin M, Allen R, Sidman C, Proetzel G, Calvin D, et al. 1992. Targeted disruption of the mouse transforming growth factor- $\beta 1$ gene results in multifocal inflammatory disease. Nature 359: 693-699.

Sime PJ, Xing Z, Graham FL, Csaky KG, Gauldie J. 1997. Adenovector-mediated gene transfer of active transforming growth factor- $\beta 1$ induces prolonged severe fibrosis in rat lung. J Clin Invest 100: 768-776.

Soro S, Orecchia A, Morbidelli L, Lacal PM, Morea V, Ballmer-Hofer K, Ruffini F, Ziche M, D’Atri S, Zambruno $\mathrm{G}$, et al. 2008. A proangiogenic peptide derived from vascular endothelial growth factor receptor-1 acts through $\alpha 5 \beta 1$ integrin. Blood 111: 3479-3488.

Spessotto P, Cervi M, Mucignat MT, Mungiguerra G, Sartoretto I, Doliana R, Colombatti A. 2003. $\beta 1$ Integrindependent cell adhesion to EMILIN-1 is mediated by the gClq domain. J Biol Chem 278: 6160-6167.

Sterner-Kock A, Thorey IS, Koli K, Wempe F, Otte J, Bangsow T, Kuhlmeier K, Kirchner T, Jin S, Keski-Oja J, et al. 2002. Disruption of the gene encoding the latent transforming growth factor- $\beta$ binding protein 4 (LTBP-4) causes abnormal lung development, cardiomyopathy, and colorectal cancer. Genes Dev 16: 2264-2273.

Streuli CH, Akhtar N. 2009. Signal co-operation between integrins and other receptor systems. Biochem J 418: 491-506.

Tatti O, Vehvilainen P, Lehti K, Keski-Oja J. 2008. MT1-MMP releases latent TGF- $\beta 1$ from endothelial cell extracellular matrix via proteolytic processing of LTBP-1. Exp Cell Res 314: 2501-2514.

Taya Y, O'Kane S, Ferguson MW. 1999. Pathogenesis of cleft palate in TGF- $\beta 3$ knockout mice. Development 126: 3869-3879.

Todorovic V, Frendewey D, Gutstein DE, Chen Y, Freyer L, Finnegan E, Liu F, Murphy A, Valenzuela D, Yancopoulos $G$, et al. 2007. Long form of latent TGF- $\beta$ binding protein 1 (Ltbp1L) is essential for cardiac outflow tract septation and remodeling. Development 134: 3723-3732.

Trask BC, Trask TM, Broekelmann T, Mecham RP. 2000. The microfibrillar proteins MAGP-1 and fibrillin-1 form a ternary complex with the chondroitin sulfate proteoglycan decorin. Mol Biol Cell 11: 1499-1507. 
TGF- $\beta$, Integrins, and EC Matrix

Uchinami H, Seki E, Brenner DA, D’Armiento J. 2006. Loss of MMP 13 attenuates murine hepatic injury and fibrosis during cholestasis. Hepatology 44: 420-429.

Unsold C, Hyytiainen M, Bruckner-Tuderman L, Keski-Oja J. 2001. Latent TGF- $\beta$ binding protein LTBP-1 contain three potential extracellular matrix interacting domains. J Cell Sci 114: 187-197.

Vehvilainen P, Hyytiainen M, Keski-Oja J. 2009. Matrix association of latent TGF- $\beta$ binding protein-2 (LTBP-2) is dependent on fibrillin-1. J Cell Physiol 221: 586-593.

Vlahakis NE, Young BA, Atakilit A, Hawkridge AE, Issaka RB, Boudreau N, Sheppard D. 2007. Integrin $\alpha 9 \beta 1$ directly binds to vascular endothelial growth factor (VEGF)-A and contributes to VEGF-A-induced angiogenesis. J Biol Chem 282: 15187-15196.

Walton KL, Makanji Y, Chen J, Wilce MC, Chan KL, Robertson DM, Harrison CA. 2010. Two distinct regions of latency-associated peptide coordinate stability of the latent transforming growth factor- $\beta 1$ complex. $J$ Biol Chem 285: 17029-17037.

Wickstrom SA, Radovanac K, Fässler R. 2011. Genetic analyses of integrin signaling. Cold Spring Harb Perspect Biol 3: a005116.
Wipff PJ, Rifkin DB, Meister JJ, Hinz B. 2007. Myofibroblast contraction activates latent TGF- $\beta 1$ from the extracellular matrix. J Cell Biol 179: 1311-1323.

Yang Z, Mu Z, Dabovic B, Jurukovski V, Yu D, Sung J, Xiong $\mathrm{X}$, Munger JS. 2007. Absence of integrin-mediated TGF $\beta 1$ activation in vivo recapitulates the phenotype of TGFß1-null mice. J Cell Biol 176: 787-793.

Zacchigna L, Vecchione C, Notte A, Cordenonsi M, Dupont S, Maretto S, Cifelli G, Ferrari A, Maffei A, Fabbro C, et al. 2006. Emilin1 links TGF- $\beta$ maturation to blood pressure homeostasis. Cell 124: 929-942.

Zaidel-Bar R, Geiger B. 2010. The switchable integrin adhesome. J Cell Sci 123: 1385-1388.

Zaidel-Bar R, Itzkovitz S, Ma'ayan A, Iyengar R, Geiger B. 2007. Functional atlas of the integrin adhesome. Nat Cell Biol 9: 858-867.

Zambruno G, Marchisio PC, Marconi A, Vaschieri C, Melchiori A, Giannetti A, De Luca M. 1995. Transforming growth factor- $\beta 1$ modulates $\beta 1$ and $\beta 5$ integrin receptors and induces the de novo expression of the $\alpha \mathrm{v} \beta 6$ heterodimer in normal human keratinocytes: Implications for wound healing. J Cell Biol 129: 853-865. 


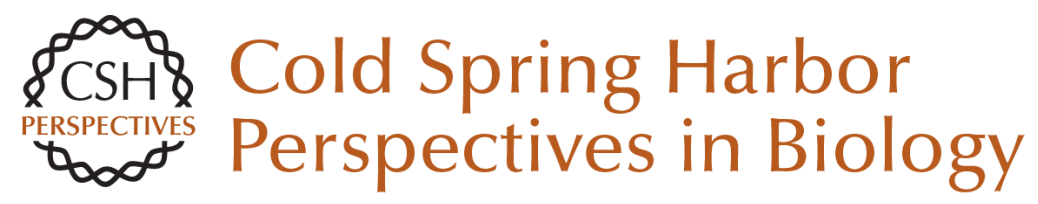

\title{
Cross Talk among TGF- $\beta$ Signaling Pathways, Integrins, and the Extracellular Matrix
}

\author{
John S. Munger and Dean Sheppard
}

Cold Spring Harb Perspect Biol 2011; doi: 10.1101/cshperspect.a005017 originally published online September 7, 2011

Subject Collection Extracellular Matrix Biology

Extracellular Matrix in Development: Insights from Mechanisms Conserved between Invertebrates and Vertebrates

Nicholas H. Brown

Extracellular Matrix Proteins in Hemostasis and Thrombosis

Wolfgang Bergmeier and Richard O. Hynes

The Thrombospondins

Josephine C. Adams and Jack Lawler

Cross Talk among TGF- $\beta$ Signaling Pathways, Integrins, and the Extracellular Matrix John S. Munger and Dean Sheppard

Heparan Sulfate Proteoglycans Stephane Sarrazin, William C. Lamanna and Jeffrey D. Esko

The Collagen Family Sylvie Ricard-Blum

Tenascins and the Importance of Adhesion Modulation

Ruth Chiquet-Ehrismann and Richard P. Tucker

Integrin Structure, Activation, and Interactions lain D. Campbell and Martin J. Humphries
Extracellular Matrix Degradation and Remodeling in Development and Disease

Pengfei Lu, Ken Takai, Valerie M. Weaver, et al.

Overview of the Matrisome--An Inventory of

Extracellular Matrix Constituents and Functions

Richard O. Hynes and Alexandra Naba

Integrins in Cell Migration

Anna Huttenlocher and Alan Rick Horwitz

Fibronectins, Their Fibrillogenesis, and In Vivo

Functions

Jean E. Schwarzbauer and Douglas W. DeSimone

Extracellular Matrix: Functions in the Nervous

System

Claudia S. Barros, Santos J. Franco and Ulrich Müller

Molecular Architecture and Function of Matrix

Adhesions

Benjamin Geiger and Kenneth M. Yamada

Cell-Extracellular Matrix Interactions in Normal and Diseased Skin

Fiona M. Watt and Hironobu Fujiwara

Genetic Analyses of Integrin Signaling

Sara A. Wickström, Korana Radovanac and

Reinhard Fässler

For additional articles in this collection, see http://cshperspectives.cshlp.org/cgi/collection/

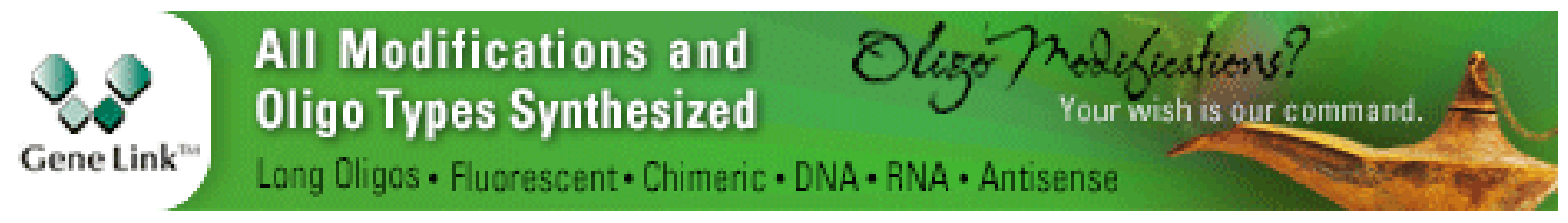

Copyright @ 2011 Cold Spring Harbor Laboratory Press; all rights reserved 